\title{
Přirozený svět nepřirozené fenomenologie a konstruovaný svět naturalistické filosofie
}

\section{David Rybák}

\section{Envigogika 14 (1) - Recenzované články / Reviewed Articles}

Published/ Publikováno 23. 06. 2019

DOI: $\underline{10.14712 / 18023061.588}$

\begin{abstract}
Abstrakt
Objev karteziánského metodického rámce revolucionizoval vědu. Ale bez ohledu na nepopiratelné úspěchy má tento rámec též svá omezení. Abychom poodhalili některá $z$ těchto omezení, vycházíme $z$ diskuse Husserlovy fenomenologie s naturalismem a naturalistickým pojetím světa a člověka, jak ho Ize nalézt u Johna Locka. Ve druhé části textu se zabýváme Husserlovým střetem s novou vědou, etnologií, jak ji rozvinul Lucien Lévi-Bruhl. Husserl viděl $v$ etnologii možnost rozvinout nový typ vědění o člověku, který by prekročil hranice (přírodo)vědy, redukující člověka na pouhý objekt ve světě.
\end{abstract}

\section{Klíčová slova}

Edmund Husserl, fenomenologie, žitý svět, konstrukce

\begin{abstract}
The invention of Cartesian methodological approach has revolutionized science. However, regardless of its undeniable achievements, this approach has also its limitations. In order to uncover some of these limitations, first, we elaborate on Husserl's discussion of John Locke's naturalism and naturalistic concept of the world and man. In the second part, we discuss Husserl's clash with the new science, i.e., ethnology, as further developed by Lévi-Bruhl. Husserl considered ethnology as a potential way for developing a new kind of knowledge about man going beyond the boundaries of (natural) sciences that reduce man to a mere object in the world.
\end{abstract}

\section{Key words}

Edmund Husserl, phenomenology, lifeworld, construction 


\section{Úvod}

$\checkmark$ tomto textu chceme sledovat některé klíčové motivy Husserlova konceptu živého a žitého či přirozeného světa $v$ diskusi s metodickým rámcem metafyziky vědomí, stojícím na metodách provádějících analýzu $v$ horizontu skutečnosti. Proto se $v$ první polovině textu zabýváme Husserlovou diskusí s naturalismem Johna Locka. Dotázání naturalistického postoje moderní prírodovědy umožňuje rozvinutí nového typu vědění o člověku a zkoumání člověka a lidských společenství žijících $v$ přirozeném světě, které nebude redukovat člověka na pouhý objekt vědění a předmět ve světě. Proto chceme $v$ dalším ukázat, že pozdní Husserl nalézá novou speciální vědu ve stavu zrodu, která je podle něho využitelná pro analýzy přirozeného světa. Tyto analýzy již nebudou mít charakter vřaditelnosti do mathesis universalis. Novou speciální vědou, o které je řeč, je etnologie, a to zejména v provedení Luciena Lévi-Bruhla. Husserlovu náčrtu možnosti využití nově otevřeného vědeckého pole pro obecnější apriorní fenomenologické analýzy žitého světa a společenství v něm žijících se bude věnovat druhá část textu.

Husserlova fenomenologie je jím samým charakterizována jako nepřirozený postoj. Nepřirozený je proto, že nesituuje sám sebe do (přirozeného) světa, ale tématizuje půdu, z niž teprve je soupatřičnost já a světa smysluplná. ${ }^{1}$ Proti tomu nese s sebou prrírodovědná metoda podle Husserla specifickou ontologii tělesovosti podle předobrazu metody fyzikálněchemické. ${ }^{2}$ Právě toto ontologické omezení př́rodovědy je Husserlem kritizováno. Husserlova fenomenologie je vedena nikoliv nějakou předem přijatou ontologií, ale naopak se chce dotazovat věcí samých na jejich způsob a smysl bytí: "Pravá metoda následuje přirozenosti záležitostí, které je potřeba probádat, nikoliv naše předsudky nebo vzory." 3 Tento metodický prístup, domníváme se, má svou relevanci i pro problematiku přírody. Nebot́ bez předchozího metodického zamyšlení by každé zachraňování prírody a života bylo jenom další technologickou protetikou. To je obecnější souvislost, díky níž si následující text nenárokuje být pouhou speciální studií k jednomu aspektu Husserlova ideového života, ale je možné mu rozumět i z nároků naší živé přítomnosti.

\section{Problém světa a přírody jako konstrukce v karteziánském metodic- kém rámci v diskusi s Lockovým empirismem}

Husserla inspirovaly $v$ jeho analýzách žitého světa antropologické a etnologické výzkumy Luciena Lévy-Bruhla. ${ }^{4}$ Abychom si ale vyjasnili smysl této inspirace pro analytický

\footnotetext{
${ }^{1} \mathrm{~K}$ charakteristice filosofického sebezamyšlení jako nepřirozeného postoje srov. Husserl, Edmund. Erste Philosophie: Text nach Husserliana VII und VIII. Hamburg: Felix Meiner Verlag, 1992, s. 121. (Dále cituji jako EPh.)

${ }^{2}$ Viz Husserl, Edmund. Filosofie jako př́sná věda. Praha: Togga, 2013, s. 30[26]. (Vycházíme z překladu Aleše Nováka a po jeho vzoru udáváme $v$ hranatých závorkách též stránkování podle 25. svazku řady Husserliana: Husserl, Edmund. Aufsätze und Vorträge: 1911-1921. Dordrecht: Nijhoff, 1987. ISBN 90247-3216-6.)

${ }^{3}$ Tamt.

${ }^{4}$ Mluvíme-li ale o "výzkumech", je třeba tomu rozumět pouze přeneseně, nebot' v případě Lévi-Bruhlově šlo o ryze teoretickou práci a interpretaci textů, cestopisů a zpráv o cizích, neevropských společenstvích. Srov. k tomu Lévi-Strauss, Claude. Strukturální antropologie. Praha: Argo, 2006, s. 313. Je přitom potřeba vidět, že Lévi-Bruhl a Lévi-Strauss se pohybují každý na jiné teoretické rovině. Lévi-Bruhl otevírá pomocí filosofického zamyšlení nad nesamozřejmostí samozřejmosti zakoušení našeho světa nový prostor zkoumání a zaměřuje ho na nový typ předmětností, který by vůbec nebyl viditelný. A teprve do takto otevřeného prostoru se může nastěhovat speciálně-vědní metodika ověřování. To jsou ale dva
} 
záběr žité zkušenosti, učiňme malou okliku směrem $\mathrm{k}$ půdě předpokladů, které fungují v novověké metafyzice vědomí ohledně problému světa a zkušenosti. Touto oklikou bude metodický rámec empirismu, který $v$ horizontu koloniální expanze Evropy rozpracovává John Locke.

Tento otec liberalismu ze svého empirického stanoviska promýšlí nový typ zkušenosti, totiž koloniální zkušenosti s neevropskými národy. A snaží se namísto dogmatického předpokladu universálních, bohem svému stvoření v podobě vrozených idejí daných forem zkušenosti, nalézt invariantní formu zkušenosti jako duševního procesu. Lépe řečeno, myšlenkové nástroje, které má $\mathrm{k}$ dispozici, jsou zároveň nástroji výkladu této zkušenosti, takže jeho výklad je opětným znovupotvrzením použitých myšlenkových nástrojů a výkladových schémat. Locke odhaluje jednak relativnost různých kultur a náboženství, ${ }^{5}$ morálních zásad a zvyků, či obecněji praktických principů, ${ }^{6}$ jednak skrze tuto relativnost též univerzální půdu, která je např́č různými společenstvími totožná.

Jenomže Lockův pokus nalézt to irrelativní ve všech kulturně a dějinně relativních podobách a systémech zkušenosti vede $\mathrm{k}$ půdě, kterou má Locke již předem připravenu, $k$ půdě vědomí, pojatého jako $v$ prírodě se vyskytující duše člověka, $v$ níž probíhají zkušenostní procesy. ${ }^{7}$ Locke konstatuje na počátku svého zkoumání, že rozum ve svých výkonech nám sice umožňuje zakoušet věci, ale nikoliv sám sebe. $K$ tomu je třeba učinit rozum sobě samému v jeho výkonech objektem: „Rozum, právě tak jako oko, zatímco nám umožňuje vidět a vnímat všechny ostatní věci, nezaznamenává sám sebe; vyžaduje obratnost a úsilí poodsunout ho na jistou vzdálenost a učinit ho sobě samému objektem. " ${ }^{8}$ Této možnosti objektivizovat sebe sama ř́ká Locke "reflexe". ${ }^{9} \mathrm{~V}$ tom je též rozhodnuto, že smyslem bytí rozumových procesů v nejširším smyslu je být objektem, předmětem vědomí.

Na půdě vědomí jako subjektu zkušenosti učiněného objektem zkoumání, nalézáme ideje jako objekty, které jsou dále organizovány reflexivním, vnitřním smyslem, jímž se mysl obrací sama na sebe. Přitom jsou vnímány činnosti naší mysli v jejích operacích, $v$ nichž je mysl vztažena ke svým vlastním idejím jako k objektům. ${ }^{10}$ Locke tedy sice odmítá na jednu stranu nějaké předem dané vrozené či apriorní ideje dané nám bohem, na druhou stranu ale předem předpokládá, že mysl disponuje logickými operacemi, nebot́ tyto operace $v$ mysli empiricky nalézá v jejich faktickém výskytu. Na jednu stranu je tak v "odteologizování" podmínek možnosti naší zkušenosti odemčena otázka po zdrojích platnosti, po legitimizaci našeho poznávání v jeho produktivních výkonech. Na druhou stranu je opět uzamčena, nebot́

úplně odlišné metodické přístupy, a především ten druhý by nebyl vůbec možný bez toho prvního, bez filosofického zamyšlení a objevu.

${ }^{5}$ Locke, John. Esej o lidském rozumu. Praha: Svoboda, 1984, s. 359.

${ }^{6}$ Srov. Tamt., s. 55-7.

7 Srov. Husserlovo vyzdvižení předpokladů fungujících v Lockově empirické psychologii: „Duše je reálno uzavřené pro sebe jako těleso; v naivní naturalismu chápe duši jako jakýsi samostatný prostor a $v$ jeho proslulém obraze je to tabulka na psaní, na niž duševní data přicházejí a odcházejí." Husserl, Edmund. Krize evropských věd a transcendentální fenomenologie: úvod do fenomenologické filosofie. Praha: Academia, 1996, s. 108. (Dále cituji jako Krize.)

${ }^{8}$ Locke, John. Esej o lidském rozumu, s. 38.

9 "Druhým pramenem, z něhož zkušenost vybavuje rozum ideami, je vnímání činností naší vlastní mysli v nás samých, když se zabývá ideami, které před tím získala ... Tento zdroj idejí má každý člověk zcela v sobě" - Locke nazývá tento zdroj ",vnitřním smyslem' - tj. "reflexí'." Locke, John. Esej o lidském rozumu, s. 75.

${ }^{10}$ Srov. k tomu Lockovu charakteristiku základních mechanismů zkušenosti: Locke, John. Esej o lidském rozumu. Praha: Svoboda, 1984, 45-7. 
logické operace mysli jsou sice empiricky konstatovány, ale jejich možnost sama není vyjasněna, Locke ji naopak předem předpokládá.

Když Locke sleduje organizující operace mysli, prostě předpokládá předem, že mysl disponuje operacemi srovnávání, abstrahování atd., v nichž se teprve reflexí podle něho ustavuje př́slušná předmětnost. Co je přitom ale klíčové: ve zmíněných Lockových předpokladech mají svět a věci ve světě povahu produktů vzešlých z reflexivně-logických operací, aplikovaných na smyslové vněmy, sensace. Zdánlivě tedy Lockův empirismus vychází ze zkušenosti, vpravdě ale je tato zkušenost již předem vřazena do logických forem. Empirie empirismu je tak již předem, aniž by se to stalo problémem, zasazena do horizontu logického. ${ }^{11}$ Svět jako horizont, ve kterém se zkušenost, potkávání něčeho jako něčeho odehrává, je již předem interpretován z logických kategorií.

Je sice pravdou, že se u Locka rodí důležitá otázka po produktivitě rozumu, že se tedy proměňuje základní metafyzický rámec stvoření v otázku po činnosti rozumu. Ale klíč pro zodpovězení otázky rozumu zůstává nezměněn. Už předem v proměně zkušenosti na souvislost objektů vědomí je rozhodnuto o tom, co bude viditelné a co ne. To společné všem lidem nejsou vrozené ideje dané stvořitelem, ale smyslově daná data vědomí a logické operace, v nichž se reflexivně mysl vztahuje sama na sebe. Tato "základna" produktivismů vědomí je podle Locka tím společným pro všechny lidi. Proti tomu konkrétní zkušenostní data, a typy operací na ně uplatněných, jsou základem rozdílu mezi zkušenostními systémy, systémy idejí. Každé zvláštní společenství má své vlastní prostředí, a toto prostředí je zdrojem odlišných smyslových dat i jejich řetězců a konstelací. Jeho členové procházejí odlišnými zkušenostmi než členové jiného společenství. Proto jsou též systémy idejí, zformované z různých zkušeností, odlišné.

"Svět" u Locka nevystupuje jako problém. Naopak, produktivismy mysli jsou samy předem "nalézány" tak, aby vyprodukovaly smysluplné věci ve světě. Je ale úplnou záhadou, čím jsou tyto produktivismy řízeny, proč z daného svazku vněmů a vjemů produkují právě takovou a takovou jednotu, ba proč vůbec produkují nějakou jednotu. Právě na tento problém poukázal David Hume, byt́ jaksi negativně ve svém skepticismu: na půdě produkujícího vědomí se všechny jednoty věcí stávají pouhou fikcí.

\section{Descartovsko-galileovská metoda jako úskok od věcí samých}

Kde je původ právě konstatované ztráty věcnosti věcí? $V$ descartovsko-galileovské metodě, $v$ analyzování celku zkušenostní danosti na skutečné části, na jasné a zřetelné představy, je cosi podstatného přehlédnuto a ztraceno. Je přehlédnuta samotná danost něčeho jako něčeho, která je samozřejmým a neproblematickým východiskem každé analýzy. Aby mohla nastoupit lockeovská analýza zkušenosti, musíme již předem předpokládat zkušenostní jednoty s jejich podstatou dávání něčeho jako něčeho. Ale právě tato podstata, která předchází veškerému analyzování, je u Locka přehlédnuta. Analyzování se děje již v horizontu skutečnosti, v němž vědění získává povahu vysvětlování, vědění o př́činách účinků.

\footnotetext{
${ }^{11} \mathrm{~K}$ tomu srov. Hegelův výklad empirismu: „Poznání je nejprve analytické; objekt pro ně má podobu zjednotlivění a činnost analytického poznání směřuje k tomu, aby odvodilo naskýtající se mu jednotlivost z nějakého obecna. Myšlení zde má pouze význam abstrakce nebo formální identity. To je stanovisko, na kterém stojí Locke a všichni empirikové." Hegel, Georg W. F. Malá logika. Praha: Svoboda, 1992, s. 350.
} 
Ale přitom je ztracena ze zřetele podstata, která není ničím skutečným, nic nepůsobí, a není tedy viditelná na rovině účinků, bez níž se ale něco jako něco neukazuje.

Vidím-li např́klad tuto knihu se vším, co patří k tomu, že se mi ukazuje jako kniha a analyzuji-li tuto zkušenost na jasně a zřetelně dané počitky vědomí, není vůbec viditelné, jak z těchto počitků opět složím zkušenostní danost knihy, pokud jsem již předem nerozuměl významovému celku "kniha". Tento významový celek není možné v analyzovaných počitcích nikde najít, tvoří naopak původní jednotu, s Husserlem vyjádřeno charakter aktového vědomí v prožitku vnímání něčeho jako něčeho. Nebo ještě jednodušeji, když rozložím hrníček na části, dno, stěny, ouško, $v$ těchto skutečných částech již nikde hrničkovitost, to, co dělá z hrníčku hrníček, nenalézám. Ještě závažněji se tato analytická souvislost projevuje v oblasti živého: rozložím-li na části živou bytost, málokdy se stane, že by po zpětném složení znovu ožila. Něco podstatného se $v$ metodickém rozkladu ztrácí, totiž právě podstata zkoumané věci, která sama není ničím skutečným. Ale podstatu a korelativně věc samu $v$ jejím živoucím a žitém jevení konstruovat nelze.

\section{Husserlova kritika Lockovy teorie soudu a reflexe}

Pokusíme se nyní využít Husserlovy kritiky Lockovy koncepce reflexe jako zdroje logických kategorií, jak je provedena především v § 44 šestého Logického zkoumání. Navažme ale nejprve na předchozí úvahu o zpředmětňující karteziánské metodě. Předmětný rozvrh musí již předem vědět o podstatě zkoumané věci, aby mohl provádět metodickou privaci a resoluci, ale tuto podstatu nevyjasňuje. Proč? Podstata sama není předmětem v horizontu skutečnosti. $K$ uvolnění a zpř́stupnění podstatových struktur naší zkušenosti by bylo potřeba získat distanci ne jen od předmětů zkušenosti, ale též od této zkušenosti jako předmětu. Musela by se získat distance od horizontu skutečnosti samotné.

Původní apodikticky evidentní danost něčeho jako něčeho nemůže být rezultátem poznání pojatého jako produkce. Nebot' odkud se ví, že poznání je takto logicky produkující? Odkud se berou logické formy, z nichž se potom konstruuje zkušenost? A odkud se bere vědění o platnosti těchto logických forem? Apodiktická danost vědomí něčeho jako něčeho musí být naopak východiskem, měřítkem všeho poznávání, ne teprve jeho produktem.

Učinit z věcí předmětné produkty reflexivních operací mysli, obrácené na sebe samu, znamená redukovat tyto věci na mysl samotnou, resp. na její produkty, myslet ji z horizontu produkce. Ale z půdy vědomí jako subjektu představ, pokud je subjektivita subjektu interpretována jako součást světa, tedy jako produkce těchto představ, nikdy nelze získat věci samotné. Totiž nelze je získat jinak, než jejich odvozením z produktivity, z produktivních operací subjektu.

Pro Locka je v předmětném horizontu viditelná pouze tato produktivita reflexe. „Reflexe" je přitom metaforou fyzikálně-optickou a označuje proces ohybu paprsku, který se lomí na reflektoru a mění svůj směr podle zákonů optiky. ${ }^{12}$ Psychické akty jakožto stavy mysli jsou patrně pro Locka takovým reflektorem. Ale $v$ tomto procesu reflexe nenalézáme nikde věci samotné $v$ jejich bytí, resp. jejich bytí je právě redukováno na produktivitu reflexe samotné. Ve fenomenologickém postoji Husserl souhlasí, že např́iklad myšlenka soudu se

\footnotetext{
12 Datování na titulní stránce prvního vydání Lockova Eseje o lidském rozumu je r. 1690. V té době byl již znám Newtonův zrcadlový, resp. reflektorový dalekohled, který byl schopen soustředit rozptýlené světlo pozorovaných hvězd.
} 
vyplňuje ve vnitřním názoru právě prováděného souzení. ${ }^{13}$ Jinak řečeno, fenomenologicky má Locke pravdu, pokud tvrdí, že reflexe dává názor kategoriálních aktů.

Husserl ale nesouhlasí s tím, že by lockovský typ reflexe byl schopen tematizovat předmětný korelát vnitřního názoru, věc samu, která je $v$ názoru samodána. $V$ případě souzení jde o totiž samotný stav věcí (Sachverhalt), myšlenku (Gedanke) "jest". ${ }^{14}$ Pokud nechceme tvrdit, že věci ve svém bytí a ve své kategoriální artikulaci jsou reflexí produkovány a zrušit tak věcnost věcí samotných, a tedy vůbec možnost mít je dány a vyjasnit je $v$ jejich bytí, je třeba rozbít metafyzický předpoklad produkce $v$ horizontu skutečnosti.

$K$ tomuto rozbití je třeba zmíněného uvolnění půdy subjektivity $z$ horizontu skutečnosti, $v$ němž je subjektivita subjektu omezena jenom na funkci producenta představ. Locke a celá novověká metafyzická tradice, stojící na karteziánské půdě vědomí interpretovaného jako součást světa, má před sebou viditelnou jenom omezenou část toho, co je, pokud to je. Dívá se totiž pouze ve smyslu a směru produkce na produkované jako produkované. Ale produkování samo jako zdroj bytí produkovaného je ve svém smyslu nedotázáno. A nedotázáno je tím způsobem, že je právě již předem rozhodnuto, že smyslem bytí je "být produkován v operacích mysli". ${ }^{15}$

Lockův pohled je omezen na vnitřní operace mysli, ale toto operování samo se mu problémem nestává. Jak je ale schopna aplikace logického operování zachytit věci $v$ evidenci, $v$ jejich samosti? Odkud víme např. o hrníčkovitosti hrníčku? $\vee$ jaké reflexi by tato podstata vyvstávala? Proč a jak je uplatněním logických operací na objektivizované obsahy mysli takováto jednota typu "hrníček" nebo "strom" vyprodukována?

Je třeba sestoupit na hlubší půdu vědomí, která není pouze produktivní, ale též smyslkonstituující. V Logických zkoumáních Husserl ještě tématicky neobjevuje problém světa. ${ }^{16}$ Přesněji řečeno, nezkoumá jeho konstituci, omezuje se na konstituci logické sféry $v$ kategoriálních aktech $v$ celé její stupňovité výstavbě od prostých objektivujících aktů. Ale i v takovémto vymezení problémového pole na půdě intencionality logických aktů je viditelný základní rozdíl mezi jsoucím stavem věcí (Sachverhalt) a evidencí, v níz se tento stav věcí konstituuje jako jsoucí. Nebo korelativně mezi bytím ve smyslu soudové kopuly a bytím ve smyslu evidence, $v$ níž se príslušný soud konstituuje. ${ }^{17}$

Husserl upozorňuje na to, že díváme-li se na jsoucí korelát souzení a korelativně na vyjádřený soud, nesmí toto bytí $v$ něm a skrze něj vyjádřené, být zaměněno za bytí ve smyslu soudové evidence (Urteilsevidenz) a korelativně soudové pravdy (Urteilswahrheit). ${ }^{18}$ Ve vyjádřeném subjekt-predikátovém soudu jsme zaměřeni na spojení subjektu a predikátu,

13 „Der Gedanke Urteil erfüllt sich in der inneren Anschauung eines aktuellen Urteils". Husserl, Edmund. Logische Untersuchungen II/2. Tübingen: Max Niemeyer, 1980, s. 139. ("Myšlenka soud se vyplňuje ve vnitřním názoru aktuelního soudu.") (Pokud uvádím německý originál i český překlad, je překlad můj.)

14 Věta z minulé poznámky pokračuje: „... aber nicht erfüllt sich darin die Gedanke des ist." Tamt. („.... ale $v$ tom se nevyplňuje myšlenka onoho jest.")

${ }^{15}$ Dáváme do závorek, abychom vyzdvihli významově jednotnou souvislost, která rozvrhuje příslušný smysl bytí.

${ }^{16}$ To je ale dáno tématem Logických zkoumání. Problém světa se tak v Logických zkoumáních objevuje právě v souvislosti s tázáním po způsobu bytí logična. Srov. např. Husserl, Edmund. Logische Untersuchungen II/2, s. 200.

${ }_{17}$ Husserl, Edmund. Logische Untersuchungen II/2, s. 124.

18 Tamt. 
které je částečnou identifikací. ${ }^{19}$ Ale tato identifikace sama, odkud pochází její smysl a platnost? Zdroj smyslu a platnosti nelze $v$ soudu nikde nalézt, není $v$ př́slušném soudu vyjádřen. To ale neznamená, že by smysl bytí soudové pravdy byl nepř́stupný. Ten, kdo př́slušný soud vyjadřuje, přece prožívá evidenci krytí vyjadřovaného soudu s nazíraným, nebo alespoň $\mathrm{k}$ jeho prožitku patři vědomí možnosti provedení tohoto krytí. A toto krytí významové intence a vnímání př́slušného stavu věcí (Sachverhaltswahrnehmung) již není částečné, jako je tomu při spojení subjektu a predikátu, ale totální. ${ }^{20}$ Nebot' se v tomto druhém krytí nekryje vyjádřený subjekt s predikátem, který je mu přisouzen, ale soudící vědomí se souzeným stavem věcí.

Máme tu tedy rozdíl mezi sférou logického vyjadřování stavů věcí a mezi souzením samotným, které je zdrojem evidence př́slušné soudové platnosti, $v$ němž teprve př́slušný soudový smysl, či jak Husserl vyjadřuje v textech kolem přednášek k Fenomenologické psychologii, jest-vztah (Ist-Verhalt) či jest-ota (Ist-heit), pramení. ${ }^{21}$ Důležité přitom je, že toto prožívané souzení samo nelze zahlédnout $z$ ontické roviny vyjádřeného stavu věcí. Ono samo není žádným stavem věcí.

Jistě, mohu toto souzení samo zpředmětnit, a to tak, že soudím o svém souzení, zaměřit se naň jako na stav věcí, např. "Já soudím, že tato kniha má zelenou obálku." Ale potom se soud "kniha má zelenou obálku" a onen první soud nekryjí ve významové jednotě, která jimi prochází. Řečeno jazykem Logických zkoumání, nekryjí se jejich matérie či smysl pojetí. Opět tu bude $v$ latenci prožívající instance, která je zdrojem platnosti príslušného soudu, ale nebude $v$ soudu explicite vyjádřena.

Locke podle Husserla řeší tento problém původu soudového smyslu bytí prostě tak, že ho neřeší. Zkrátka ztotožňuje souzení a stav věcí, o kterém se soudí. Zatímco Descartes ještě rozlišuje ve struktuře ego cogito dva momenty, cogitatio a cogitatum, Locke tento základní rozdíl opomíjí. ${ }^{22}$ Nevystupuje mimo sféru vědomí s jeho daty a logickými operacemi, a pokud jde o skutečnost věcí ve světě, musí se vposledku odvolat na boha. ${ }^{23}$ To, s čím se setkáváme, jsou pro Locka data vědomí a jejich organizace $v$ produktivitě mysli. Jestli a pokud vůbec tato organizace může odpovídat nějakým věcem ve světě, to se Lockovi nestává vážným problémem, který by otřásl předpoklady, na nichž jeho empirismus stojí.

Zároveň ale, aby vůbec mohl disponovat věcnými jednotami produkovanými v mysli, Locke musí předpokládat půdu přírody jako korelátu přírodovědných objektivací již předem. ${ }^{24} Z$ ní si přece bere smysluplnost a věcnost věcí jako surovinu pro svou analýzu, $v$ níž se ovšem, jak jsme již viděli, právě tato smysluplnost a věcnost vytrácí. Ze sensuálních dat již nelze sestavit zpětně danou věc, např́klad knihu, nebot́ jednak jsou tato data daty vědomí, jednak není srozumitelné, odkud by se ve vědomí vzala tato významová jednota „kniha", pokud by vědomí vždycky už nějak touto jednotou nedisponovalo. Totiž není to

\footnotetext{
19 Tamt.

20 "In der Evidenz handelt es sich um totale Deckung". Tamt.

${ }^{21}$ Viz Husserl, Edmund. Phänomenologische Psychologie. Hamburg: Felix Meiner Verlag, 2003, s. 95-6.

22 Srov. např. Husserl, Edmund. Krize, s. 108.

${ }^{23}$ Srov.: „Pokud jde o mě, myslím si, že mi Bủh dal dostatečné ujištění o existenci věcí mimo mě; vždyt' dík jejich rozmanitému působení mohu v sobě vyvolat jak slast, tak i strast, což je pro můj současný stav nejdůležitější." Locke, John. Esej o lidském rozumu, s. 344.

${ }^{24}$ Srov. "In Lockes Vorgehen so wie in dem aller naturalistischen (anthropologistischen, psychologistischen) Vernunfttheorien liegt also eine Art widersinniger Zirkel. Es setzt als geltend Natur, Naturwissenschaft voraus, während es zugleich nach der Möglichkeit ihrer Geltung fragt." Husserl, Edmund. EPh, s. 96. („V Lockově postupu, tak jako ve všech (antropologických, psychologistických) teoriích mysli je př́tomen druh protismyslného kruhu. Předpokládá se jako platná příroda, prrírodověda, a zároveň se stává problémem možnost jejich platnosti.")
} 
srozumitelné potud, pokud touto jednotou nedisponujeme a nepředpokládáme ji již předem, namísto abychom se ji pokusili vyjasnit v jejím původu.

Domyslíme-li dále sledované problémové souvislosti, v horizontu skutečnosti, $v$ němž je myšlena též duše, není pochopitelné, jak by nějaká organizace dat mohla zachytit něco, co je, nakolik to je, jako korelát evidence. Nebot́ soudem jistě mohu vypovídat o něčem skutečném a v psychologické apercepci na půdě světa snad mohu též uznat, že tomuto soudovému vypovídání o skutečném odpovídá též nějaký skutečný proces ve světě. Ale pravdivost nebo nepravdivost jako korelát evidence, resp. prožitku totálního krytí soudového myšlení s vypovídaným stavem věcí, nemůže být skutečná a závislá na skutečnosti. Nebot' př́slušný stav věcí (např. bytí-knihy-zelenou) nemíním přece s tím smyslem, že ho ve svém souzení produkuji, že tedy vzniká teprve v mém souzení, jakkoliv by se mi bez tohoto mého souzení nejevil.

\section{Naturalizace a psychologizace světa}

Viděli jsme, že Locke sleduje vědomí v horizontu skutečnosti, tedy jako proces organizace představ. Pojímá aktivity vědomí jako objekty, resp. jako prostoročasové procesy, ale $v$ tom je věcnost věcí, resp. to, co je ve vědomí vědomo, redukováno na pouhý výtvor př́slušné organizace. Bytí věcí se $v$ tomto rozložení na data vědomí a jejich následném spojování ztratilo z dohledu.

Husserl mluví o tom, že Locke "stojí naprosto v naturalistickém postoji a ego pojímá jako duši v předem daném světě". ${ }^{25}$ Odkud pochází tato „předem danost" světa? Jinak řečeno, jak a odkud ví Locke o smyslu bytí světa? Soudové a obecně kategoriální formace jsou pro něho, alespoň v Husserlově interpretaci, kterou zde sledujeme, výsledkem reflexe, organizující předem daná data vědomí. Sledovali jsme již, že Locke si sice činí problémem produkci předmětné stránky zkušenosti, ale že zároveň již předem pojímá tuto produkci jako souvislost logických operací. Tak je úpIně přehlédnuto, že svět, resp. věci v něm zakoušené, jsou již předem pojaty jako zkušenostní jednoty, jako výsledek produktivně-logických operací vědomí.

Jak jsme viděli, Locke odhaluje nesamozřejmost evropské normality. Ukazuje, že křestáanská morálka, idea boha, zkrátka celý systém představ vlastní křestáanské Evropě, není ničím universálním. Jsou jiné možné systémy zkušenosti a představ, které jsou stejně oprávněné, nakolik jsou produkovány logickými operacemi naší mysli a opřeny o příslušné zkušenostní jednoty. Přitom se naše náboženství, morálka, politika ukazují být jenom jednou z podob systému zkušenosti, tedy nejsou něčím vrozeným, absolutním a pro všechny lidi na světě společným.

Při uplatnění analýzy v prostoročasové apercepci, Locke předpokládá jako samožrejmost, že prostoročasová jednota světa je výsledkem logických "operací naší mysli". Přesněji, "svět" vůbec není pro Locka viditelnou předmětností, jejiž konstitucí by se zabýval. Svět přece není žádným předmětem ve smyslu konfigurace představ povstávající z reflexe. Je naopak samozřejmou onto-logickou formou skutečného jako skutečného, do něhož Lockovi patř́ jak duševní, tak tělesové.

25 „... ganz naturalistisch eingestellt, das ego als Seele in der vorgegebenen Welt". Husserl, Edmund. EPh., s. 75 . 
Co tedy Locke již předem "vii" o světě? Především to, že svět je souvislostí příčin a účinků. ${ }^{26}$ Skutečnost jako souvislost př́čin a účinků není tím, co by chtěl vyjasnit $v$ jejím způsobu a smyslu bytí, je naopak samozřejmým východiskem, samozřejmou rovinou jeho uvažování. Zároveň se tato skutečnost $v$ jeho analýze zdvojuje: skutečnost je výsledkem logických operací mysli, a zároveň mysl samotná je již předem zasazena do souvislosti skutečné př́rody, do souvislosti př́činnosti. Co chce Locke vysvětlit, je produkce produktu, představových jednot vzniklých z reflexivních operací rozumu. Ale tato druhá rovina produktu $v$ sobě nenese žádnou nutnost, má formu faktickou, formu faktické organizace idejí, k níz patří, že by mohla být také jinak nebo nemusela být vůbec; že by z daného "materiálu" sensací byl vyprodukován jiný systém idejí.

Porovnáme-li nyní krátce Lockovu metodu rozkladu na psychická data s fenomenologickým postupem, ukáže se nám základní rozdíl v tom, že ve fenomenologickém záběru sledujeme podstatu př́slušných intencionálních aktů, a ne faktické spojení počitků v psychických aktech ve smyslu př́rodního procesu. Nepředpokládáme jako Locke mysl jako př́rodní jsoucno, na něž působí v horizontu skutečnosti vnější příčiny. V Lockově naturalistickém východisku se věci ve své věcnosti vytrácí z viditelnosti, jsou vykazatelné jenom jako agregáty představ, spojených logickými operacemi. Ale to, co ustavuje jejich věcnost, vůbec není učiněno problémem. Podstatná nutnost, která konstituuje věc jako věc $v$ její podstatě, je z roviny analýzy a syntézy skutečných představ neviditelná. Podstata knížky např́klad není ničím skutečným, není na tomto přírodním tělese nikde nalezitelná. Tato rovina podstatného je přesně tím, co se vytratilo při analýze a syntéze $v$ horizontu skutečnosti, psychična jako součásti př́rody.

\section{Žitý svět a etnologie}

Pokusili jsme se předvést některé důležité body Husserlovy kritiky metodického rámce moderní prírodovědy. Stojí za to nyní sledovat, že pozdní Husserl nalézá novou vědu, která mu otevírá problémovou půdu pro jeho vlastní apriorní zkoumání intersubjektivní konstituce žitého světa. Touto vědou je etnologie. Na konci 20. let se Husserl seznamuje s prací Luciena Lévi-Bruhla Duchovní svět primitivü. ${ }^{27}$

Proč právě etnologie? Husserl ve svých zkoumáních fenoménu dějinnosti a naň navázaných nových problémů konstituce a dějinného apriori dochází ke vhledu do nemožnosti universální mathese ve smyslu raně novověkých projektů (př́rodo)vědy, která by do svého geometrického rozvrhu pojímala též duše. A to především z toho důvodu, že titul "rozum" v sobě obsahuje možnosti neustálého vyjasňování, neustálého překračování vlastních výtěžků a odhalování jejich zdrojů a předpokladů ke stále hlubším evidencím. Jak to Husserl vyjadřuje: „Není člověk rozumovou bytostí tím, že jeho způsob bytí spěje ke stále vyššímu stupni sebeujasnění a že jeho rozumovost může být bytostně uskutečněna jen ve vlastní reflektované rozumovosti a úsilím o její růst?"28

\footnotetext{
${ }^{26}$ „Pokud jde o jednoduché ideje ze smyslového vnímání, je třeba uvážit, že cokoli je tak uspořádáno v prírodě, že je schopno podrážděním našich smyslů způsobit nějaký vjem v mysli, právě tím vyvolává v rozumu jednoduchou ideu; a ta, at́ už je její vnější příčinou cokoli, jakmile si jí jednou povšimne naše rozlišovací schopnost, je myslí posuzována jako reálná pozitivní idea v rozumu jako kterákoli jiná (a takto se tam o ní uvažuje), i když nelze vyloučit, že její příčinou je možná nějaký nedostatek v objektu." Locke, John. Esej o lidském rozumu, s. 92.

27 V roce 1929 dostal Husserl tuto knihu s věnováním od autora. Srov. Schuhmann, Karl. Husserl-Chronik: Denk- und Lebensweg Edmund Husserls. Haag: Nijhoff, 1977, s. 340.

${ }^{28}$ Husserl, Edmund. Krize, s. 457.
} 
Husserl si vyjasňuje možnosti této nové vědy, etnologie, toho, jak je možné, že někdo $z$ vědců může překročit svůj zvláštní svět, své osvětí, konstituované uvnitř evropských dějin směrem k osvětím naprosto cizím, stojícím a odehrávajícím se do značné míry mimo evropské dějiny: „Pro primitiva existuje osvětí s lidmi, ale s lidmi jako je on sám, ne s lidmi, kteří by měli pro něho nepředstavitelnou personální strukturu, vědec' spolu s pro něho nepředstavitelnými aktivitami logicko-vědeckého jednání. Na druhou stranu, jeho duchovní druh, jeho duchovní činnosti, jeho předem dané osvětí můžeme my vědecky pokročilí, nějaký LéviBruhl, systematicky odhalovat." 29

Má-li být možná věda o lidských intersubjektivně konstituovaných společenstvích s jim korelativním osvětím $v$ universálním smyslu, tj. též mimo evropský dějinný horizont, k němuž jako spolu-konstituens patří platnost vědy, musí být možné, jakkoliv třeba ponejprv bez výslovného dotázání, v horizontu vědeckého úsilí o vědění tento vědecký horizont překročit. Není $v$ tom ale zároveň obsažen protismysl? Jak by bylo možné $v$ teoreticko-vědeckém horizontu vědění tento horizont zároveň překročit? Poznávám-li uvnitř oborů mimolidského jsoucího, tento problém ovšem nevzniká, nebot takové jsoucí nemá ve svém způsobu bytí možnost sebe-překračování, kterou vyjadřuje titul "rozum". Je tak možné zajistit apriorní materiálně-ontologický rámec čistých možností pro zkoumané jsoucí v jeho způsobu a smyslu bytí. Jak ale u bytosti, $\mathrm{k}$ jejímuž způsobu bytí patří možnost překračovat jakoukoliv apriorně-ontickou danost?

Musí zde být rovina, která je společným zdrojem smyslu pro před-vědecké i pro vědecké lidství. Touto rovinou je právě žitý svět. Přitom musí Husserl předpokládat, že i v předvědecké zkušenosti přirozeného postoje konstitutivně panuje podstatná nutnost, kterou je možné $v$ př́slušných reduktivních postupech zpřístupnit a v čistém zření explikovat.

"Transcendentální subjektivita" je Husserlovi titulem pro strukturu a půdu této podstatné nutnosti, ale strukturou nikoliv v ideálním, resp. idealizovaném smyslu, nýbrž v dění, $v$ toku jako pra-fenoménu veškeré konstituce. Není zde předem daná logická identita, z níž by byla rozvíjena obsažnost transcendentální subjektivity. Naopak čisté možnosti jsou odhalovány v příslušných konstitutivních zkoumáních. Není žádná samostatná půda transcendentální subjektivity jako půdy čistých možností. Takové vytržení transcendentálního do samostatnosti by znamenalo umělou abstrakci, a především opuštění principu všech principů. K fungující transcendentální subjektivitě patří paradoxní "oklika" skrze faktické provádění života, přičemž ale ve fakticitě je tato transcendentální subjektivita vždy již anonymně, na sebe samu nezaměřena, fungující.

Je třeba upozornit na dvojznačnost, která vzniká zasazením problematiky žitého světa do dějinného horizontu se základní hranicí před-vědeckého a vědeckého. Tato dvojznačnost spočivá v tom, že titul "žitý svět" může označovat konstituent nějakého před-vědeckého lidství, ale zároveň (a primárně) vždy též transcendentální konstituens smyslu, které překračuje toto rozlišení vědeckého a před-vědeckého světa. $V$ tomto druhém a primárním smyslu je obsažena problematika zpětného vsazení teoretických výtěžků do přirozeného světa a postoje, tvorba předsudků vyššího řádu, vzniklých tím, že výtěžky minulé teoretické

\footnotetext{
29 „Für den Primitiven gibt es eine Umwelt mit Menschen, aber mit Menschen seinesgleichen, nicht mit Menschen, die für inn die unvorstellbare personale Struktur, Wissenschaftler' haben, mit für inn unvorstellbaren Aktivitäten des logisch-wissenschaftlichen Tuns. Andererseits, seine Geistesart, seine Geistestätigkeiten, seine vorgegebene Umwelt können wir wissenschaftlich Entwickelte, kann ein Lévy-Bruhl systematisch enthüllen." Husserl, Edmund. Die Lebenswelt: Auslegungen der vorgegebenen Welt und ihrer Konstitution : Texte aus dem Nachlass (1916-1937). Dordrecht: Springer, 2008, s. 54. (Dále cituji jako Lebenswelt.)
} 
evidence se stávají novými podklady samožrejmosti a ve formě sedimentů, opětně zatemněných a ve vší samozřejmosti fungujících "klubek" smyslu se zpětně včleňují do apercepcí přirozeného postoje. Tato problematika je sice Husserlem vyzdvižena, ale pokud je mi známo $z$ dostupných textů, zůstává ve svých konstitutivních problémech téměř nerozvinuta. Ani my se touto problematikou zabývat nebudeme, nebot́ vybočuje z našeho tématu.

Husserl ovšem ve svém zájmu o Lévy-Bruhlovu etnologii nemá snahu pokračovat či navázat na novou speciální vědu. Nechce nově objevený prostor proměnit v novou předmětnou specializaci, do které se nastěhují speciálně-vědní výzkumníci, kteří převezmou filosofický objev jako samozřejmost a budou zkoumat nové typy prostoročasových předmětů. Stojí za účelem výkazu toho podívat se na Husserlův dopis Lévi-Bruhlovi, ${ }^{30}$ který je cenný právě tím, že se v něm Husserl snaží ukázat celkovější filosofické možnosti, které jsou otevřeny etnologií s jejím novým objektem zkoumání. Jde podle Husserla o novou oblast konstitutivních zkoumání, vztažených k čistě duchovědné antropologii a čisté psychologii, která bude osvobozena ze zúžení na oblast skutečnosti, jako jsme to viděli u Locka. Připomeňme, že Locke sice přichází s důrazem na fakticky existující mnohost systémů idejí, ${ }^{31}$ ale zároveň uzavírá tuto mnohost do téže souvislosti prrírody jako skutečnostní formy, která je v základu jakéhokoliv systému představ.

Člověk a lidské společenství tak nebude zkoumáno pouze jako přírodní skutečnost, ne jenom jako objekty ve světě, ale jako osoby mající svět, tak jak jsou ve všem svém žití, jednání a myšlení subjekty vědomí. ${ }^{32}$ Můžeme tento program vyjádřit tak, že Husserlovi jde o dotazování a explikaci smyslu bytí člověka v intersubjektivitě a socialitě. Jeho záměr přitom je a zůstává transcendentálně-fenomenologický. Socialita není zkoumána pouze jako

30 Jak referuje Herbert Spiegelberg (a v tom se ukazuje něco typického pro Husserlovy snahy rozšírit fenomenologický záběr do vědeckého povědomí), po přečtení Husserlova dopisu se Lévi-Bruhl obrátil na Arona Gurwitsche s prosbou: „Expliquez-moi, je n'en comprends rien." („Vysvětlete mi to, já ničemu z toho nerozumím.") Srov. Schuhmann, Karl. Husserl-Chronik: Denk- und Lebensweg Edmund Husserls, s. 459.

31 Jak známo, francouzští teoretici v explicitní návaznosti na Lockův empirismus začnou zkoumat tyto systémy idejí a jejich původ. Destutt de Tracy, Cabanis, kteří sami sebe nazývají „ideology", přicházejí s názvem ideologie jako "obecné nauky o idejích". Naess, Arne Main. Democracy, Ideology, and Objectivity: Studies in the Semantics and Cognitive Analysis of Ideological Controversy. Oslo: University Press, 1956, s. 148. Přitom tato nauka je podle nich součástí zoologie, nikoliv metafyziky nebo teologie. Tamt., s. 151. To je v souladu s Husserlovou kritikou naturalizace vědomí v lockovské linii - naturalizaci vědomí odpovídá naturalizace člověka jako zvířete $v$ řádu zoologickém. Zároveň ale se mísí $s$ tímto lockeovsko-osvícenským teoretickým rámcem též kantovský kriticismus s jeho titulem Weltanschauung z 26. paragrafu Kritiky soudnosti. V tomto textu jde o „pohled na svět”, který se odehrává jako uplatnění nadsmyslové schopnosti mysli požadovat totalitu, "sjednocení do jednoho názoru" i tam, kde tento názor sám být dán nemůže. Srov. Kant, Immanuel. Kritika soudnosti. Praha: Odeon, 1975, s. 88.

$32 \mathrm{~K}$ tomu celému srov. "An einem grossen und besonders wichtigen Gebiet ist die Möglichkeit und unbedingte Notwendigkeit einer rein geisteswissenschaftlichen Anthropologie sichtlich geworden - also wie ich auch sagen könnte, reiner Psychologie, die die Menschen nicht als Naturobjekte, nicht psychophysisch im Universum der raum-zeitlichen Realitäten (in der objektiven, naturwissenschaftlichen Raum-Zeitlichkeit) behandelt, sondern als Personen, als Bewusstseinssubjekte betrachtet, so wie sie sich selbst konkret finden und mit den Personalpronomina nennen." Husserl, Edmund. Briefwechsel. Band VII: Wissenschaftlerkorrespondenz. The Hague: Kluwer Academic Publishers, 1994, s. 161-2. ("Na velikém a obzvláště důležitém oboru se stala viditelnou možnost a nepodmíněná nutnost čistě duchovědné antropologie - tedy, jak také mohu říci, čisté psychologie, která nezachází s lidmi jako s prrírodními objekty, psychofyzicky $v$ universu prostoročasových realit ( $v$ objektivní, př́rodovědné prostoročasovosti), nýbrž sleduje je jako osoby, jako subjekty vědomí, tak jak sebe sami konkrétně nalézají a oslovují se pomocí osobních zájmen.") 
objektivní svazky reálných lidí, ale v jejím konstitutivním smyslu; ne jako přírodní prostoročasová realita, ale jako duchovní výtvor, k němuž patři též smysl vzájemné propletenosti jednotlivých jáství.

Husserl se tak v Lévi-Bruhlově etnologii domnívá nalézat novou vědu ve stavu zrodu, zatím nefixovanou jako předmětný obor zabývající se svými předměty, ale mající ještě živé vědomí svého založení ve filosofickém dotázání rozdílnosti, která se netýká pouze lidí jako prostoročasových jsoucen, ale rozdílnosti světů. ${ }^{33}$ Tedy, můžeme domyslet, různosti způsobů bytí ve světě. Je tedy možno studovat nikoliv pouze objektivní nebo pouze subjektivní stránku tohoto bytí, ale ve "vcítění dotázat konstituci př́slušného intersubjektivního společenství. A to, můžeme dodat, aniž bychom předpokládali předmětný rámec, který jako vědecky poučení Evropané vkládáme do každého teoreticky zpřístupňovaného tématu. A stejně tak, aniž bychom předpokládali svůj, evropský svět, v němž je opět implicitně již jistý smysl společenské vzájemnosti obsažen.

Tak je otevřen prostor pro zkoumání specifické konstituce „Vzájemné vztaženosti". Souslovím "vzájemná vztaženost" překládáme Husserlův termín "miteinander", který interpretujeme právě jako konstitutivní propletenost monadických jáství. $V$ ní se korelativně konstituuje též samotný smysl druhého jako druhého a v tom též souvislost "mne" jako někoho, kdo je tu pro toto druhé já atd. Důležité je, že přitom tento smysl "druhého" není předpokládán předem v předpokladu objektivního světa. Jiná společenství tak nejsou redukována na nějakou variantu "nás" samotných, tj. na náš svět. Právě smysl jiného světa je teprve $v$ př́slušných reduktivních zpřistupněních možno dotázat.

V tomto smyslu oceňuje Husserl Levi-Bruhlovu práci: „Ale oproti této prázdné obecnosti nás Vaše dílo a Vaše význačné téma učinilo vnímavými vưči něčemu převratně novému: totiž že je možným a nejvýše důležitým a velikým úkolem, vcítit se' do žijící generativní sociality izolovaně žijícího lidství a rozumět mu jako majícímu svět ze svého sociálně jednotného života, který není ,představou světa', nýbrž pro toto společenství skutečně jsoucím světem." 34 Stojí za to všimnout Husserlova explicitního rozlišení mezi "představou světa" (Weltvorstellung) a "skutečně jsoucím světem" jako, dodejme, korelátem přirozeného postoje. Nebot' i veškerá řeč o "světonázoru", „ideologii" či "představě světa" předpokládá již novověkou metafyziku představujícího subjektu. A každé myšlení, které si tohoto není vědomo, je odsouzeno neustále budovat namísto světa nějaký realizovaný systém představ o světě, namísto světa idealizovanou substrukci. ${ }^{35}$ Klíčovým je Husserlův důraz na transcendentálně konstitutivní záběr etnologického zkoumání, který není omezen pouze na prírodně-

\footnotetext{
${ }_{33}$ Pro jistotu připomínáme, že tyto zvláštní světy předpokládají formu jednoho společného světa a zároveň jistou obsažnou společnou půdu, na niž se tyto světy mohou potkat.

34 "Aber gegenüber dieser leeren Allgemeinheit hat Ihr Werk und Ihr ausgezeichnetes Thema ein überwältigend Neues uns empfindlich gemacht: nämlich dass es eine mögliche und höchst wichtige und grosse Aufgabe ist, uns in eine in lebendiger generativer Sozialität abgeschlossen lebende Menschheit "einzufühlen" und sie zu verstehen als in ihrem sozial vereinheitlichten Leben und aus ihm die Welt habend, die für sie nicht "Weltvorstellung", sondern die für sie wirklich seiende Welt ist." HUSSERL, Edmund. Briefwechsel. Band VII: Wissenschaftlerkorrespondenz, s. 162.

${ }^{35}$ Obecněji viděno, zachycuje rozlišení mezi představou světa a světem jako konstituovaným v Urdoxa rozdíl mezi pasívně-zkušenostní danostní světa a aktivním výkladem světa, konstrukcí. Srov. „Wie eine Vorstellung überhaupt, so habe ich die Weltvorstellung nicht bloß als aktuelles Erlebnis, als Erzeugnis, sondern als aus dem Erzeugen erworbenen Besitz." HUSSERL, Edmund. Lebenswelt, s. 76. ("Tak jako mám představu vůbec, nemám též představu světa prostě jako aktuelní prožitek, jako konstrukci, nýbrž jako z konstruování vytěžené vlastnictví. Jednotlivou věc zakouším a získávám o ní představu díky konstruujícímu ,výkladu' jejího bytí v podstatě.")
} 
psychologický popis systémů idejí, ale na transcendentální souvislost konstituce př́slušného intersubjektivního společenství a korelativně jemu náležejícího světa.

Proti tomu Husserl oceňuje právě objevení možnosti přístupu ke světu jiného společenství, aniž bychom předem skrze vědecký rámec objektivizující idealizace vtahovali jinakost jiných do světa našeho jako pouhou jeho součást. Je třeba naopak studovat jinakost z ní samé, sledovat př́slušné systémy víry a systémy apercepcí: „Přitom se můžeme naučit rozumět jejich způsobům apercepce, identifikování, myšlení, tedy jejich logice spolu s ontologií jejich osvětí a jemu přináležejícími kategoriemi."36

Husserl vyzdvihuje specifičnost společenství „primitivư", které se vyznačuje "bezdějinností" (Geschichtslosigkeit), nemají jako společenství před sebou budoucnostní horizont národa. To stojí v kontrastu s naším evropským světem, který je podle Husserla význačný právě vázaností na národ a jeho dějinný horizont. Zpětně, $v$ tomto kontrastu tedy vystupují úkoly analýzy vnitřní struktury národa $v$ jeho sociálních zvláštních společenstvích, dále ontologické analýzy osvětí korelativního k typu nadnároda (Übernation) jako společenství národů. Můžeme dodat, že takové zkoumání konstituce a vnitřních vztahů této intersubjektivity vyššího řádu je jednou ze stránek Husserlových analýz intersubjektivity a žitého světa, které by rozhodně vyjasnilo mnohé problémy naší prítomnosti. Spokojíme se zde jenom s poukázáním na možné využití fenomenologie pro porozumění prítomnosti planetarizovaného světa, pro bližší zkoumání zde ovšem není prostor.

Konečně Husserl v dopise stručně načrtává problematiku absolutního ego, či, jak vyjasňuje dále: „totiž Já, které nalézám já, filosofující, jako mé poslední Já, zpětným dotázáním (Rückfrage) po subjektu aktů (Vollzugssubjekt) metodou fenomenologické redukce všeho mého světa a sebeapercepcí". ${ }^{37}$ Teprve tato půda absolutního Já zpř́stupňuje horizont vědomí (Bewusstseinshorizont), na němž mají všechny světské i sociální platnosti ustaveny svůj smysl a platnost. ${ }^{38}$ Tento odkaz na konstitutivní funkci absolutního Já uvádí Husserl proto, aby odlišil fenomenologicko-transcendentální záběr od pozitivního vědění, do něhož mu patří též antropologie. Toto pozitivní vědění je naivním potud, pokud nesestupuje k poslednímu zdroji platnosti a smyslu. A to proto, můžeme dodat, že se stále pohybuje na již ustavené půdě světa, kterou předpokládá jako samozřejmou a zasazuje na ni též všechny ostatní konstitutivní jednoty: „Pozitivní věda je konsekventně objektivní vědou, vědou v samozřejmosti bytí objektivního světa a lidského bytí jako reálné existence ve světě." 39 Proti tomu transcendentální fenomenologie umožňuje odkrýt jako problém tuto samozřejmost "Svět a my lidé ve světě" a zkoumat její konstituci. ${ }^{40}$

\footnotetext{
36 "Dabei lernen wir verstehen ihre Arten zu apperzipieren, zu identifizieren, zu denken, also ihre Logik sowie ihre Ontologie, die ihrer Umwelt mit den zugehörigen Kategorien." Tamt., s. 162.

37 "nämlich das Ich, das ich, der Philosophierende, durch Rückfrage nach dem Vollzugssubjekt in der Methode der phänomenologischen Reduktion aller meiner Welt und Selbstapperzeptionen als mein letztes Ich finde". Tamt., s. 163.

38 "Denn in dessen Bewusstseinshorizont haben alle Sozialitäten und ihre relativen Umwelten Sinn und Geltung aufgebaut und bauen diese im Wandel immer neu weiter." Tamt. ("Nebot' v jeho horizontu vědomí mají všechny sociality a jejich relativní osvětí ustaven smysl a platnost a ustavují tento smysl v proměně stále nově dále.")

39 "Positive Wissenschaft ist konsequent objektive Wissenschaft, ist Wissenschaft in der Selbstverständlichkeit des Seins der objektiven Welt und des menschlichen Seins als realen Daseins in der Welt." Tamt.

40 Tamt.
} 


\section{Závěrem}

Předmětný rámec moderní (přírodo)vědy se pohybuje v horizontu skutečnosti, tj. prostoročasově lokalizovatelných tělesových částí s apriori vlastním této tělesovosti. Analyzuje jsoucí, a to i živé jsoucí, na skutečné kusy, aby izoloval jednotlivé příčinné či alespoň pravděpodobnostní vztahy. Tyto kusy jsou opětně, po analýze ovšem již kontrolovanými kroky skládány dohromady, přičemž se zkoumají funkcionální vztahy a závislosti mezi jednotlivými částmi uvnitř celku. Poukazovali jsme na to, že při tomto rozložení na části se cosi podstatného ztrácí. Opačně viděno: vbudování živých bytostí do idealizovaných předmětných struktur a modelů vede nutně $\mathrm{k}$ závažnému zásahu do jejich přirozenosti.

Porozumění právě načrtnuté problematice metody je, domníváme se, jedním z důležitých přínosủ Husserlovy fenomenologie pro naši přítomnost. Nejde zde o to, prostě odmítnout, nebo naopak přijmout konstruktivní metodické postupy. Vždyt' celý náš moderní svět a život je na nich a v nich zbudován. Jde o to, otevř́t si tuto dějinnou situaci samu jako problém. Nebot ignorování problému vbudování moderního člověka a jeho světa do idealizovaných drah by znamenalo, že veškeré pokusy o zachování přirozenosti a přírody budou znamenat jenom další rozšírení konstruujících a plánovaných systémů, at' už by se tyto systémy jakkoliv intenzívně natíraly na zeleno.

\section{Literatura:}

- Hegel, Georg Wilhelm Friedrich. Malá logika: encyklopedie filozofických věd. I. díl. Vydání I. Praha: Svoboda, 1992. ISBN 80-205-0153-3.

- Husserl, Edmund. Aufsätze und Vorträge: 1911-1921. Dordrecht: Nijhoff, 1987. ISBN 90-247-3216-6.

- Husserl, Edmund. Briefwechsel. Band VII: Wissenschaftlerkorrespondenz. The Hague: Kluwer Academic Publishers, 1994.

- Husserl, Edmund a Rochus SOWA. Die Lebenswelt: Auslegungen der vorgegebenen Welt und ihrer Konstitution : Texte aus dem Nachlass (1916-1937). Dordrecht: Springer, 2008. Husserliana. ISBN 978-1-4020-6476-0.

- Husserl, Edmund. Erste Philosophie: Text nach Husserliana VII und VIII. Hamburg: Felix Meiner Verlag, 1992. ISBN 3-7873-1094-0.

- Husserl, Edmund a Novák, Aleš, ed. Filosofie jako přísná věda. Překlad Aleš Novák. Vyd. 1. Praha: Togga, 2013. 83 s. ISBN 978-80-7476-035-8.

- Husserl, Edmund. Krize evropských věd a transcendentální fenomenologie: úvod do fenomenologické filosofie. Vydání 2., reprint 1. vydání, Academia 1972. Praha: Academia, 1996. Filosofická knihovna. ISBN 80-200-0561-7.

- Husserl, Edmund. Logische Untersuchungen II/2. Tübingen: Max Niemeyer, 1980.

- Husserl, Edmund a Lohmar, Dieter, ed. Phänomenologische Psychologie: Text nach Husserliana, Band IX. Hamburg: Meiner, 2003. xli, 242 s. Philosophische Bibliothek; Bd. 538. ISBN 3-7873-1603-5.

- Kant, Immanuel. Kritika soudnosti. Překlad Vladimír Špalek a Walter Hansel. Vydání první. Praha: Odeon, 1975. 271 stran. 
- Lévi-Strauss, Claude. Strukturální antropologie. Praha: Argo, 2006. ISBN 80-7203713-7.

- Locke, John. Esej o lidském rozumu. Vydání I. Praha: Svoboda, 1984.

- Næss, Arne, Christophersen, Jens A. a Kvalo, Kjell. Democracy, Ideology and Objectivity: Studies in the Semantics and Cognitive Analysis of Ideological Controversy. Oslo: Univ. Press, 1956. 346 s.

- Schuhmann, Karl. Husserl-Chronik: Denk- und Lebensweg Edmund Husserls. Haag: Nijhoff, 1977. Husserliana. Dokumente. ISBN 90-247-1972-0. 